Article

\title{
Achieving Sustainable Economic Growth: Analysis of Islamic Debt and the Islamic Equity Market
}

\author{
Adil Saleem ${ }^{1, * \mathbb{C}}$, Budi Setiawan ${ }^{1}$, Judit Bárczi ${ }^{2}$ and Judit Sági ${ }^{3} \mathbb{C}$ \\ 1 Doctoral School of Economics and Regional Studies, Hungarian University of Agriculture and Life Sciences, \\ H-2100 Gödöllő, Hungary; setiawan.budi@hallgato.uni-szie.hu \\ 2 Institute of Economics, Hungarian University of Agriculture and Life Sciences, H-2100 Gödöllő, Hungary; \\ barczi.Judit@uni-mate.hu \\ 3 Faculty of Finance and Accountancy, Budapest Business School-University of Applied Sciences, \\ H-1149 Budapest, Hungary; sagi.judit@uni-bge.hu \\ * Correspondence: saleem.adil@phd.uni-szie.hu or adil.saleem927@gmail.com
}

Citation: Saleem, A.; Setiawan, B.;

Bárczi, J.; Sági, J. Achieving

Sustainable Economic Growth: Analysis of Islamic Debt and the Islamic Equity Market. Sustainability 2021, 13, 8319. https://doi.org/ $10.3390 /$ su13158319

Academic Editor: David K. Ding

Received: 27 June 2021

Accepted: 21 July 2021

Published: 26 July 2021

Publisher's Note: MDPI stays neutral with regard to jurisdictional claims in published maps and institutional affiliations.

Copyright: (c) 2021 by the authors. Licensee MDPI, Basel, Switzerland. This article is an open access article distributed under the terms and conditions of the Creative Commons Attribution (CC BY) license (https:// creativecommons.org/licenses/by/ $4.0 /)$.

\begin{abstract}
The financial sector is divided into two broad categories: equity and banking markets. The healthy functioning of these sectors plays an imperative role in any economy. This study aimed to examine the short- and long-term relationship between the Islamic financial sector (Islamic debt and Islamic equity market), and sustainable economic growth of the two economies with the largest Muslim populations. Quarterly data were collected from 2010 to 2019 for Indonesia and Pakistan. The study used autoregressive distributive lag (ARDL) and the error correction method (ECM). The results revealed that in the long run, the Islamic banking sector imparts a significant and positive effect on achieving sustainable economic growth in both countries. However, in the short run, the Islamic stock market was found to have a positive relationship with Pakistan, while the Islamic banking sector had a positive and significant relationship with economic growth in Indonesia.
\end{abstract}

Keywords: Islamic banking; Islamic stocks; ARDL; bound test; sharia banking; SDG8

JEL Classification: O47; Q01; O16; F65

\section{Introduction}

A company's profitability plays a pivotal role in the economy by creating job opportunities and contributing to the country's income source through taxes [1]. The profit of a company can be optimized through proper management of external and internal funding. Drake and Fabozzi [2] explain that the sources of capital are divided into three types: retained earnings, banking, and financial markets. Companies with high debt levels tend to choose to finance from equity, while companies with low leverage seek funding from banks [3]. Each source of funding has different consequences for the company's financial condition.

Recent stories of the COVID-19 pandemic, for instance, disrupted the liquidity of many companies. The decline in business activity due to government policies to reduce the spread of COVID-19, such as social distancing, lockdown, and curfew, has significantly affected many companies' revenue. In this situation, companies that obtain capital from banks will find it difficult to pay their debts due to limited liquidity. According to Banerjee, et al. [4], almost $50 \%$ of companies do not have sufficient cash to finance debt in the coming year. The increasing risk of default can lead to deterioration of loan quality, which can impact financial system instability [5].

Indonesia and Pakistan are the two countries with the world's largest Muslim populations, and they face severe financial problems. According to the World bank statistics, in 2017, only $49 \%$ of the population in Indonesia and 21\% in Pakistan had access to formal financial institutions. In terms of company capital structure, the size of the capitalization of 
the Islamic capital market, compared to that of the total gross domestic product (GDP) in Indonesia, was around 49\% in 2020. Meanwhile, total lending from Islamic banking was $7 \%$ of the GDP in the same year. In Pakistan, the contribution of the sharia financial sector is still below $10 \%$. In 2020, the total capitalization of the Islamic capital market and sharia banking contributed $6.83 \%$ and $0.02 \%$, respectively, to the total GDP. Levine and Zervos [6] explained that the development of both the stock market and the banking sector positively impacts economic growth.

The study of financial development toward economic growth began with Schumpeter in the early nineteenth century and continues today. Gambacorta, et al. [7] stated that both equity and debt finance play a vital role in economic growth. In contrast, Chakraborty and Ray [8] argued that bank-based financing outperforms market-based financing. DemirgucKunt, et al. [9] argued that financial structure contributes to economic growth by following the stage of financial sector development.

This study aimed to investigate Islamic finance and its relation to economic growth, focusing on debt- and equity-based financing. The research on Islamic bank-based and equity-based financing has not received sufficient attention [10,11]. Previous studies focused only on the conventional financial sector, such as the studies by Osoro and Osano [12] and Zhang, et al. [13]. The Islamic banking sector alone and stock markets alone have been studied in connection to gross domestic product $[14,15]$. However, to the best of the authors' knowledge, this study is the first to look for empirical evidence about the type (equity/debt) of the Islamic financial market that achieves sustainable economic growth. This paper intends to find which Islamic financial sector (Islamic stock market or Islamic banking) is helpful in achieving sustainable economic growth in countries with a Muslim majority.

This study contributes to the existing body of knowledge in the following ways. Firstly, this research provides novel empirical evidence that provides a comparison of Islamic financial markets (equity- vs. debt based) and their impact on economic growth in the short and long run. Secondly, the study enriches the literature from the perspective of the Islamic finance-growth nexus. Previously, the Islamic finance-growth nexus only documented the Islamic banking development or the Islamic stock market development. However, this study fills the gap by analyzing both Islamic financial sectors in connection to sustainable economic growth. Most importantly, the study highlights the defining roles for the financial regulators, brokers, and investors and outlines their contribution to promoting economic growth. In addition, this paper will have implications for regulatory authorities and the concerned ministries to foster economic growth in sustainable ways and help them to decide which sectors need regulatory intervention. Furthermore, our paper is in line with the United Nations-Sustainable Development Goals (UN-SDGs) number 8 agenda to promote financial development to achieve sustainable economic growth [16].

Using the autoregressive distributed lag (ARDL) model, this paper extends the existing literature on Islamic corporate finance structure, especially on Islamic bank and equity financing. The remainder of the paper is organized as follows: Section 2 discusses the literature review regarding bank and equity financing. The data and statistical models are shown in Section 3. Section 4 presents the empirical findings, and Section 5 includes the discussion. Section 6 presents conclusions.

\section{Literature Review}

The development and transparency of the financial sector play an essential role in promoting economic growth. The availability of various sources, such as retained earnings, bank loans, and issuance of shares, is a determining factor for a company's performance. The decision on the best source of capital is a long-standing debate with the aim of finding an optimal financial structure. Levine [17] states that debt financing can mobilize savings and allocate capital and investment, while an equity-based system encourages the society to save through firm, expert company control that facilitates risk management. Furthermore, the source of capital has implications for a company's financial costs and performance 
and collectively will have an impact on the economy. A previous study investigating corporate capital structure by comparing the impact of bank-based and equity-based financing on economic growth explained that bank-based financing positively impacted economic growth before the global financial crisis. In contrast, equity financing had a better impact than did debt financing after the subprime mortgage crisis [18].

Song and Thakor [19] provided a comprehensive theoretical base in financial infrastructure and economic growth. According to the authors, the key interactive relationship existing between the debt market and capital market is one of a competitive, coevolving, and complementary nature. Importantly, the stand-alone dominance of one market will only exist if both markets compete with each other. On the contrary, interactive relationships tend to exist if either one sector complements the other, or if both are coevolving in nature. Furthermore, Song and Thakor [20] also argued that a strong banking sector complements the development of stock markets. Hence, the coevolution of both sectors is of profound importance for better economic development. In line with the complementary relationship, a recent study by Arize, Kalu and Nkwor [10] explained that debt and equity financing complement a company's capital structure. The authors used the ARDL model to examine the importance of the banking and capital market for accelerating economic progress in Nigeria. Using monthly data from 1981 to 2014, results suggested the coevolution of debt and stock market for the progress of economy. Consistent to complementary relationship, Osoro and Osano [12] provided a similar result in Kenyan economy. Authors put forward that Kenyan economy is largely dependent on a banking system with a considerable small proportion of the capital market, but results suggested a coevolving relationship between bank- and equity-based markets.

Other studies explained that equity financing has a positive impact on economic growth as it is backed by regulations limiting speculative financial transactions, thereby reducing the systematic risk within the financial industry [21]. In addition, Abraham, et al. [22] explained that the development of the domestic financial market encourages access to capital for companies by issuing shares or bonds and a form of diversification of corporate capital sources. In terms of liquidity risk, equity-based financing positively correlates with the required stable funding and increases the company's bargaining power [23]. Furthermore, Ahmed and Wahid [24] examined the financial structure and growth relationship by employing a panel cointegration model in African countries. The study reveals that for the smooth functioning of the economy, market-based financial development plays a conducive role. However, in the long run, the banking sector is expected to facilitate growth by efficiently managing financial intermediation to the real sector.

Proponents of the debt market opined that funds flowing from the banking sector actively participate in the real sector, resulting in the growth of the economy. In contrast, investments made in the equity market are considered for a shorter period, which is sensitive to many short events [25]. Likewise, bank-based financial development was found to be dominant in Kenya. Using the ARDL model to differentiate dominance and complementary relationship between bank-based and market-based financial development, results favored the debt-based financial development for the development of real economic progress [26]. Furthermore, stand-alone dominance of bank-based financial systems has been observed in the growth-finance nexus. However, financial intermediation played a profound role in the economy depending on the financial efficiency and strength of legal status in the financial system [8]. Similarly, Rioja and Valev [27] provided overarching findings concerning the finance-growth nexus. The authors considered 62 countries to examine the sources of growth in endogenous growth models. The research concluded that bank-based and market-based financial systems are sources of growth depending upon the economic state of a country. For instance, the finding suggests that in low-income countries, debt-based financial systems are likely to dominate, whereas in high-income countries, stock markets appear to have a contributory role in achieving growth.

The studies of the company's capital structure are constantly evolving and encouraging some new findings. A recent study by Ugolini [28] found a coevolving relationship 
between banks and nonbanks in Belgium using data from the 1830s. The results revealed that it is necessary for the banks and equity markets to evolve together rather than competing with each other. In addition, theories of financial structure evolution developed through several phases, starting from competition, complementarity, and coevolution [19]. In parallel to previous studies, some recent studies contributed in favor of the banking sector and culminated that the debt market has a far-reaching impact on productivity and growth in the long run $[29,30]$.

However, there is a lack of empirical studies that examine the impact of Islamic bankand equity-based financing on economic progress. Previous research has focused on the impact of sharia financing at a micro level. For instance, Fianto, et al. [31] analyzed the correlation between debt-based and Sharia microfinance on household welfare in rural Indonesia. The study found that both financings have a positive and significant impact on the household in Indonesia. Additionally, Zarrouk, et al. [32] only considered the banking side of the Islamic financial system and suggested a unidirectional relationship that flows from Islamic financing to economic growth. Additionally, Saleem, Sági and Setiawan [14] worked on Islamic financial depth measures by financing made by Islamic banks as a percentage of GDP and the factor of financial instability in Islamic banks. The results were consistent with the supply leading theory; however, economic growth was negatively affected by financial instability in the long run. In addition, another study by Wahyudi, et al. [33] investigated debt and equity financing based on the Sharia principle, focusing on a corporate perspective, and revealed that debt and equity financing positively affect profitability. Thus far, the literature revealed financial infrastructure in relation to the conventional bank- or market-based development. However, few studies exist in the literature that review only the Islamic finance-growth nexus by analyzing the Islamic banking market and Islamic stock market to examine their dominance and the complementary relationship between them.

\section{Data and Methods}

\subsection{Model Specification}

The study aimed to examine the importance of the Islamic banking market in comparison to Islamic capital markets in achieving economic growth. Two countries with a majority of Muslim populations were chosen for this study-Indonesia and Pakistan. India, as the third most Muslim populous country, was not included in this research since it does not have an Islamic banking industry [34].

Notably, the financial sector was mainly categorized in two dimensions, i.e., banking markets and capital markets. Importantly, the dynamics of the financial sector have been changed significantly after the world economy hit by the credit crunch of 2007-2009. In this paper, GDP at the current price was taken as the dependent variable. Islamic stock market development and Islamic banking development were modeled as explanatory variables. Islamic stock market development was proxied by total Islamic market capitalization taken as a percentage of GDP. On the other hand, the total financing made by Islamic banks was taken as a percentage of GDP to represent the Islamic banking development. The model is given in the following equation:

$$
G D P_{i t}=a_{o}+a_{1} I S M_{i t}+a_{2} I B M_{i t}+u_{t}
$$

where $G D P_{i t}$ represents gross domestic product at the current price in local currency. ISM $i t$ shows the development in the Islamic stock market (ISM) at time $t$ of $i$ country. IBM $M_{i t}$ is the representation of Islamic banking market (IBM) development of $i$ country at quarter $t$, whereas $u_{t}$ is the noise term produced in the time $t$.

\subsection{Data and Material}

Quarterly economic, capital, and banking data of Indonesia and Pakistan were sourced from World Development Indicator (WDI), Pakistan Stock Exchange (PSX), Otoritas Jasa Keuangan (OJK), Statistics Indonesia (BPS), and Islamic banking Bulletin—SBP from 
2010Q1 to 2019Q4. Additionally, Table 1 illustrates the description of variables used along with sources of data collection.

Table 1. Description of variables.

\begin{tabular}{cccc}
\hline Variables & Description & Notation & Data Collection \\
\hline Economic Growth & $\begin{array}{c}\text { Real Gross Domestic } \\
\text { Product }\end{array}$ & GDP & $\begin{array}{c}\text { World Development Indicator } \\
\text { (WDI) }\end{array}$ \\
$\begin{array}{c}\text { Islamic Stock Market } \\
\text { Development }\end{array}$ & $\begin{array}{c}\text { Islamic market } \\
\text { capitalization as a } \\
\text { percentage of GDP }\end{array}$ & ISM & $\begin{array}{c}\text { Financial Services Authority } \\
\text { (Otoritas Jasa Keuangan-OJK) } \\
\text { for Indonesia. } \\
\text { Pakistan Stock Exchange (PSX) } \\
\text { for Pakistan. }\end{array}$ \\
\hline $\begin{array}{c}\text { Islamic Banking } \\
\text { Development }\end{array}$ & $\begin{array}{c}\text { Total Islamic } \\
\text { financing as a } \\
\text { percentage of GDP }\end{array}$ & IBM & $\begin{array}{c}\text { SBP's Islamic Banking bulletin } \\
\text { for Pakistan Statistics } \\
\text { Indonesia (BPS) for Indonesia }\end{array}$ \\
\hline
\end{tabular}

\subsection{Econometric Model Specification}

Based on the nature of the time series data and stationarity of the variables, we followed Pesaran, et al. [35] autoregressive distributed lag (ARDL) this study. Compared to the Johansen and Juselius [36] cointegration model, the ARDL model enjoys several benefits over other cointegration models. ARDL is efficient in testing the hypothesis even with the limited number of observations [35,37]. Furthermore, it is employed with a single equation to analyze the long-run cointegration even when the variables are modeled in different lag structures. Notably, the model is equally efficient with mixed order of stationarity among variables, i.e., I(0) or I(1). Lastly, it can control the endogenous variables and still produce valid t-statistics [38].

ARDL methodology was carried out in three steps. At first, the presence of cointegration was tested by using a bounds test to examine the null hypothesis of no cointegration. The computed F-statistics of asymptotic distribution is nonstandard; therefore, the value was compared to the given upper I(1) and lower I(0) bound critical values to accept or reject the null hypothesis (no cointegration). If the $\mathrm{F}$ value computed by the bound test was greater than the upper bound critical value, it provided evidence for rejecting the null and accepting the alternative (presence of cointegration). Secondly, once the cointegration was established, the long-run relationship was analyzed using the ARDL model. Equation (1) illustrates the ARDL bounds test to examine the impact of Islamic financial markets on economic growth.

$$
\Delta \ln (G D P)_{t}=\varnothing_{0}+\sum_{r=1}^{q 1} \sigma_{1 r} \Delta \ln (G D P)_{t-r}+\sum_{r=0}^{q 2} \sigma_{2 r} \Delta I S M_{t-r}+\sum_{r=0}^{q 3} \sigma_{3 r} \Delta I B M_{t-r}+\theta_{1} \ln (G D P)_{t-1}+\theta_{2} I S M_{t-1}+\theta_{3} I B M_{t-1}+\varepsilon_{t}
$$

The left-hand side of the equation represents the economic growth at time $t$. Maximum lag length is denoted by $q_{i}, \varepsilon_{t}$ is the error term in the model. ISM stands for Islamic stock market development, whereas IBM refers to Islamic banking development. The null hypothesis of no cointegration is tested as $H_{0}: \theta_{1}=\theta_{2}=\theta_{3}=0$, against the alternate for the presence of cointegration. However, after rejecting the null hypothesis, long-run estimates of variables are calculated using Equation (2).

$$
\ln (G D P)_{t}=\varnothing_{0}+\sum_{r=1}^{q 1} \sigma_{1 r} \ln (G D P)_{t-r}+\sum_{r=0}^{q 2} \sigma_{2 r} I S M_{t-r}+\sum_{r=0}^{q 3} \sigma_{3 r} \mathrm{IBM}_{t-r}+\pi_{t}
$$

$\sigma_{1 r}, \sigma_{2 r}$, and $\sigma_{3 r}$ are the long-run parameters of lagged dependent and independent variables, respectively. $\pi_{t}$ is the error term in the model. After estimating the long-run relationship, this study employed an error correction model (ECM) to examine the short-run impact of explanatory variables on GDP. ECM model is represented as Equation (3). 


$$
\Delta \ln (G D P)_{t}=\varnothing_{0}+\sum_{r=1}^{q 1} \omega_{1 r} \Delta \ln (G D P)_{t-r}+\sum_{r=0}^{q 2} \omega_{2 r} \Delta I S M_{t-r}+\sum_{r=0}^{q 3} \omega_{3 r} \Delta \mathrm{IBM}_{t-r}+\omega_{t} E C T_{t-r}+\pi_{t}
$$

where $\omega_{1 r}, \omega_{2 r}$, and $\omega_{3 r}$ are the coefficients of short-run estimated independent variables. $E C T_{t-r}$ is the error correction term, it shows the speed of adjustment to gain the long-run equilibrium state. To ensure the long-run equilibrium, the coefficient of ECT must be negative and statistically significant $[35,37,38]$. Additionally, to ensure the robustness and stability of the model, we also performed several diagnostic tests to meet the OLS assumptions. For instance, Jarque Bera test was performed to examine the normality of errors, Ramsey RESET test was run to check the model stability, Breusch Pegan test was conducted to ensure the homoscedasticity within error, and Breusch Godfrey LM test was performed to meet the requirement of no serial correlation in errors.

\section{Results}

This section provides empirical results and findings based on the models described in the previous section. In the first section, we provide the results of unit root tests in Table 2. Augmented Dicky-Fuller (ADF) and Phillip-Perron (PP) tests were performed to examine the stationarity of the variables. The results of unit root tests illustrate that variables are not stationary at the same level, i.e., I(0) and/or I(1) since the variables are stationary at mixed order; either at level or at first difference. Even with the mixed order of stationarity, the ARDL model is efficient and provides valid and unbiased estimates.

Table 2. Unit root test.

\begin{tabular}{ccccccccc}
\hline & \multicolumn{2}{c}{ Augmented Dickey-Fuller (ADF) } & \multicolumn{3}{c}{ Phillip-Perron (PP) } \\
\cline { 2 - 10 } & \multicolumn{2}{c}{ I(0) } & \multicolumn{2}{c}{ I(1) } & \multicolumn{2}{c}{ I(0) } & \multicolumn{2}{c}{ I(1) } \\
\cline { 2 - 10 } & \multicolumn{1}{c}{ C } & C + T & C & C + T & C & C + T & C & C + T \\
\hline \multirow{2}{*}{ GDP } & -1.793 & 1.931 & -7.434 & -8.925 & -3.618 & -1.703 & -6.337 & -6.846 \\
& $(0.378)$ & $(1.00)$ & $(0.000)$ & $(0.000)$ & $(0.001)$ & $(0.732)$ & $(0.00)$ & $(0.000)$ \\
\hline \multirow{2}{*}{ ISM } & -1.221 & -2.565 & -11.12 & -11.307 & -2.294 & -3.234 & -12.622 & -23.020 \\
& $(0.656)$ & $(0.297)$ & $(0.000)$ & $(0.000)$ & $(0.178)$ & $(0.091)$ & $(0.000)$ & $(0.000)$ \\
\hline \multirow{2}{*}{ IBM } & -2.024 & -1.516 & -6.923 & -7.325 & -2.225 & -1.543 & -6.9114 & -7.323 \\
& $(0.275)$ & $(0.808)$ & $(0.000)$ & $(0.000)$ & $(0.201)$ & $(0.798)$ & $(0.000)$ & $(0.000)$ \\
\hline \multirow{2}{*}{ GDP } & & & & Pakistan & & & \\
& $(0.878)$ & $(0.098)$ & $(0.000)$ & 0.010 & $(0.022)$ & $(0.000)$ & & \\
\hline \multirow{2}{*}{ ISM } & -1.748 & -1.862 & -7.922 & -8.066 & -1.602 & -1.682 & -7.974 & -8.344 \\
& $(0.400)$ & $(0.656)$ & $(0.000)$ & $(0.000)$ & $(0.472)$ & $(0.742)$ & $(0.000)$ & $(0.000)$ \\
\hline \multirow{2}{*}{ IBM } & 0.761 & -2.382 & -3.574 & -7.1468 & 0.761 & -2.382 & -6.880 & -7.121 \\
& $(0.992)$ & $(0.383)$ & $(0.011)$ & $(0.000)$ & $(0.992)$ & $(0.382)$ & $(0.000)$ & $(0.000)$ \\
\hline
\end{tabular}

$\mathrm{C}$ and $\mathrm{T}$ denotes intercept and trend.

The result of the bounds test is represented in Table 3, which provides all the specifications of the model selected for both countries. For Indonesia, the model was selected based on Schwarz info criteria (SIC) with lagged structure $(3,0,2)$, whereas the model was selected based on Akaike info criteria (AIC) with $(2,1,4)$ lagged structure for Pakistan. The model for both countries becomes stable at the given lag structures and selection criteria. Results indicate that the computed F statistics for both models are higher than the upper-bound critical values. F statistics for Indonesia and Pakistan are 12.598 and 6.14, respectively, which is greater than the upper-bound I(1) critical value at $5 \%$ significance, i.e., 3.87 . The finding of the bounds test resulted in the null hypothesis of no cointegration to be rejected. Hence, both models indicate that variables 
are cointegrated in the long run. Furthermore, Table 3 also illustrates the diagnostic tests to ensure the robustness and reliability of both models. The models are statistically robust as tests indicate that errors are homoscedastic (Breusch-Pegan test), not serially correlated (LM Godfrey test), and normally distributed (Jarque-Bera test). However, functional correctness is ensured by the Ramsey RESET test, which is not statistically significant and evident in the correct functional forms of both models.

Table 3. Bounds test.

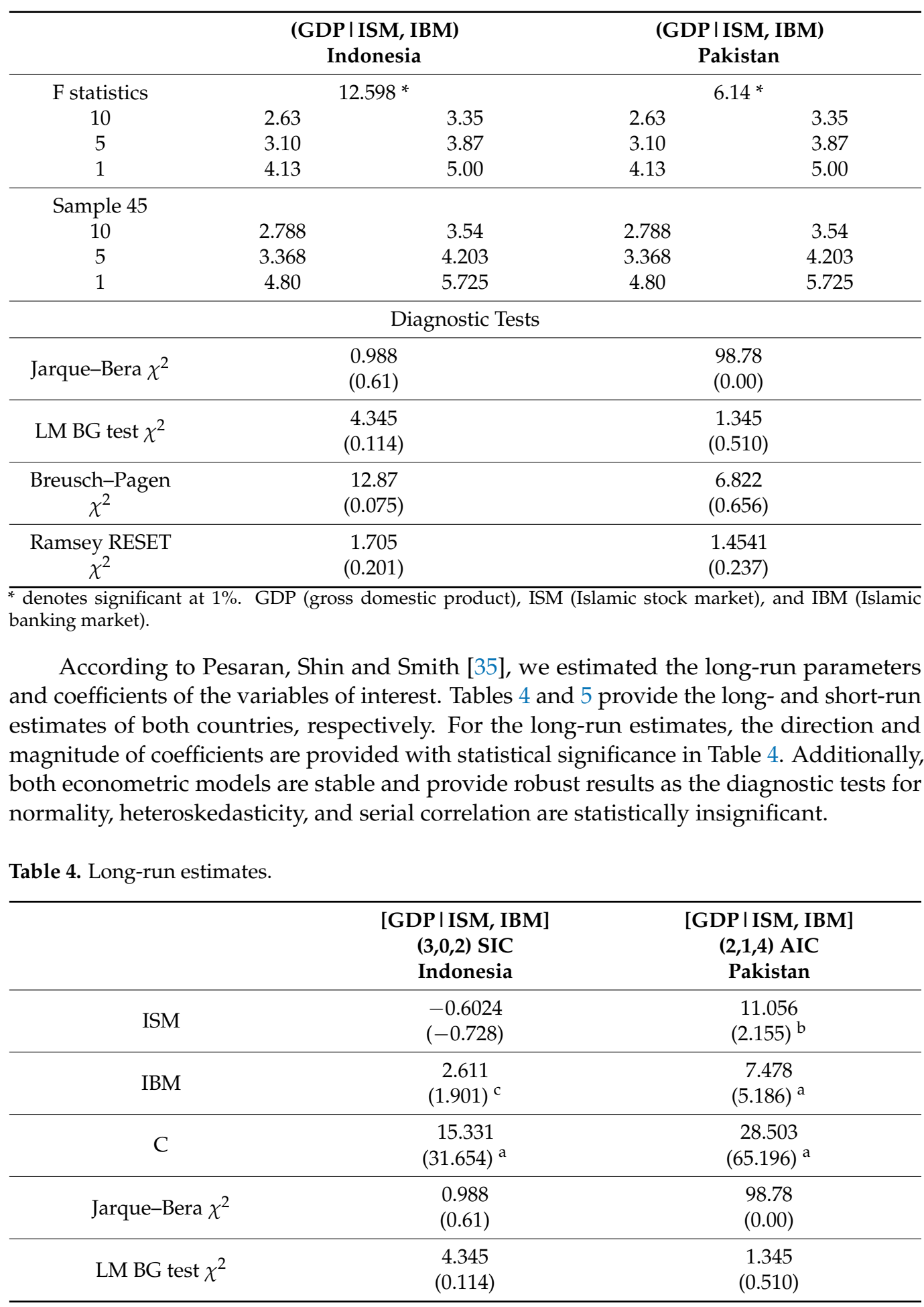


Table 4. Cont.

\begin{tabular}{ccc}
\hline Breusch-Pagen $\chi^{2}$ & 12.87 & 6.822 \\
& $(0.075)$ & $(0.656)$ \\
\hline \multirow{2}{*}{ Ramsey RESET $\chi^{2}$} & 1.705 & 1.4541 \\
$\mathrm{a}, \mathrm{b}, \mathrm{c}$ denotes significance at $1 \%, 5 \%$ and $10 \%$, respectively. SIC (Schwarz info criteria), AIC (Akaike info criteria)
\end{tabular}

GDP (gross domestic product), ISM (Islamic stock market), and IBM (Islamic banking market).

To estimate the short-run coefficient, an error correction model (ECM) was used in this study. Table 5 illustrates the differenced and lagged coefficients with the level of significance. It is found that in the short run, the Islamic banking industry provides better intermediation, resulting in economic growth. The error correction term for both countries is negative and significant at $1 \%$, which provides evidence that the model regains its equilibrium state after being disturbed in the short run. In the case of Indonesia, almost $6 \%$ of disturbance tends to gain its equilibrium position and regain the convergence position. In addition, up to $6 \%$ in the case of Indonesia and 3\% in the case of Pakistan movements from disequilibrium state gain the long-run cointegration in the next quarter. Though the speed of adjustment is not very high, the results reveal the negative coefficient, which indicates that after every disturbance, the model will move to its equilibrium state.

Table 5. Short-run estimates.

\begin{tabular}{|c|c|c|}
\hline & $\begin{array}{c}\text { [GDP | ISM, IBM] } \\
(3,0,2) \text { SIC } \\
\text { Indonesia }\end{array}$ & $\begin{array}{c}\text { [GDP | ISM, IBM] } \\
(2,1,4) \text { AIC } \\
\text { Pakistan }\end{array}$ \\
\hline $\mathrm{D}(\mathrm{GDP}(-1))$ & $\begin{array}{c}-0.013 \\
(-0.119)\end{array}$ & $\begin{array}{c}0.332 \\
(2.969)^{\mathrm{a}}\end{array}$ \\
\hline D(ISM) & $\begin{array}{l}-0.0355 \\
(-0.614)\end{array}$ & $\begin{array}{c}0.062 \\
(0.776)\end{array}$ \\
\hline $\mathrm{D}(\operatorname{ISM}(-1))$ & - & - \\
\hline $\mathrm{D}(\mathrm{IBM})$ & $\begin{array}{c}0.084 \\
(0.707) \\
\end{array}$ & $\begin{array}{c}-0.233 \\
(-1.477)\end{array}$ \\
\hline $\mathrm{D}(\operatorname{IBM}(-1))$ & $\begin{array}{c}0.284 \\
(2.463)^{b}\end{array}$ & $\begin{array}{c}-0.636 \\
(-3.50)^{\mathrm{a}}\end{array}$ \\
\hline $\mathrm{ECT}(-1)$ & $\begin{array}{c}-0.058 \\
(-7.414)^{\mathrm{a}}\end{array}$ & $\begin{array}{c}-0.0267 \\
(-5.197)^{\mathrm{a}}\end{array}$ \\
\hline Adjusted R-squared & 0.5296 & 0.6145 \\
\hline Log likelihood & 103.8580 & 159.029 \\
\hline Durbin-Watson stat & 2.1483 & 2.1515 \\
\hline Schwarz criterion & -4.6134 & -7.3059 \\
\hline
\end{tabular}

$\overline{\mathrm{a}, \mathrm{b}}$ denotes significance at $\%$ and $5 \%$, respectively. SIC (Schwarz info criteria), AIC (Akaike info criteria). GDP (gross domestic product), ISM (Islamic stock market), and IBM (Islamic banking market).

To ensure the reliability of the results and selected model, we performed several diagnostic tests to check the robustness. Table 3 provides a list of tests and their results. Moreover, the CUSUM test was performed to ensure the model's stability. The CUSUM test results are displayed in Figure 1. 

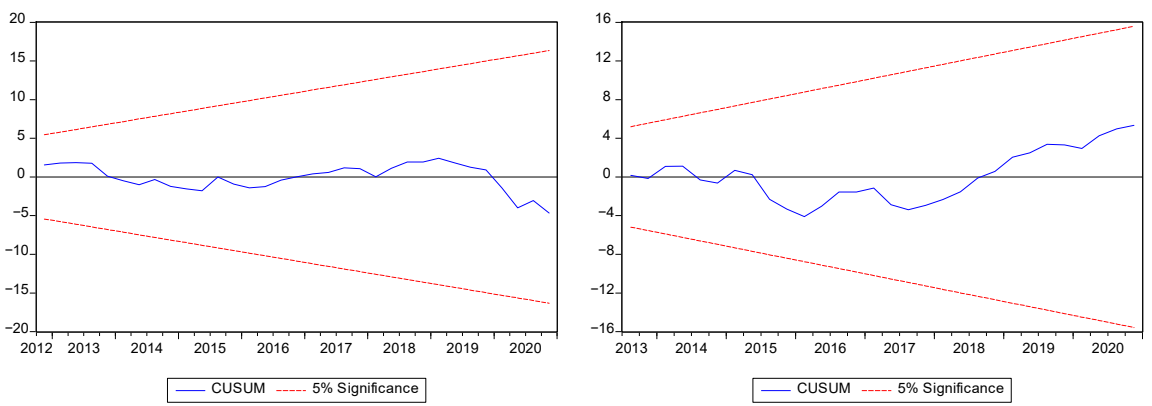

Figure 1. CUSUM test.

\section{Discussion}

This section provides a detailed discussion based on the results presented in the previous part. Our findings reveal that there is strong evidence of cointegration among variables. In the long run, results indicate that the Islamic banking market in Indonesia has a positive long-run impact on economic growth. The coefficient of Islamic banking development is 2.611, which is statistically significant at $10 \%$. However, although the Islamic capital market covers the larger share in terms of percentage of GDP, the impact of ISM is negative and not significant in the long run.

We analyzed that the depth of Islamic stock market capitalization in Indonesia reached the maximum limit of 80 percent to GDP, and the trend followed a decline to arrive at $40 \%$ by the end of 2019. The declining trend of Islamic stock market capitalization in Indonesia appeared to be unhealthy for economic growth. The stock market suffered losses due to the overall dwindling economy in the last few years. Furthermore, the manufacturing sector underperformed than expected, a continuous rise in the consumer price index and growing barriers to investments and trade caused a decline in market capitalization. On the contrary, the Islamic banking industry in Indonesia is growing with a continuous increase every quarter. Hence, the Islamic banking market in Indonesia favors economic growth in the long run; our results conform to the previous research [14]. Our results point to the dominance of Islamic banking rather than a complementary relationship with the Islamic equity market in achieving economic growth, which is also consistent with previous research $[29,30]$. The coefficient of the Islamic stock market and Islamic banking sector in Pakistan is 11.056 and 7.478, respectively. Both coefficients are statistically significant at 5\% and $1 \%$, respectively. However, the magnitude of both parameters depicts that the Islamic stock market appeared to be more influential in fostering economic growth in the long run than the Islamic bank-based market. To conclude, a coevolving phenomenon exists in the case of Pakistan, which is consistent with previous findings in conventional financial infrastructure [12,28].

In Pakistan's economic setting, both Islamic financial sectors are conducive to economic growth. The growing trend of both financial sectors is a sign of a healthy Islamic financial industry. The results concerning Islamic banking financing and its long-run impact on the economy are supported by many authors, and our results are consistent with many findings [39]. However, the Islamic stock market and its impact on economic health could not provide a unanimous outcome for the countries selected. It is largely dependent on the growth structure and stock market listing, which tend to change every year.

Based on our findings, the Islamic stock market does not contribute significantly to the short run in developing economic growth (Table 5). However, the relationship between the Islamic stock market and economic growth in Indonesia is negative in the long run, while the Islamic stock market is positively associated with economic growth, though both parameters are not the major determinants of the economic health of a country in the short run. The Islamic banking sector with its first lagged value has a significant short-run relationship with the economic health of both countries. The coefficient of IBM in Indonesia and Pakistan is 0.284 and -0.636 , which are statistically significant at $5 \%$ and $1 \%$, respectively. Importantly, the ECM model also examines the speed of adjustment from 
short-run disequilibrium to attain the equilibrium state in the long run. The finding of this research is expected to have implications on financial regulatory authorities and financial institutions. The central banks may formulate the policies specifically monetary policy to encourage the Islamic financial system, reducing the rate of interest and encouraging cheap mode of financing for the manufacturing industry. Furthermore, in developing countries, banks should promote small and medium enterprises by facilitating financing opportunities. Reducing trade and investment barriers would encourage investors and manufacturers to play their role in the development of growth since the intervention of central banks, securities, and exchange commission's coevolving stage of both Islamic financial sectors can be sustained for a longer period. In addition to regulatory authorities, our study is equally important for the management of the financial sector, especially Islamic financial players, to adapt to innovation and build a strong IT infrastructure to achieve sustainable growth (as suggested by $[40,41]$ ). The increased use of technology enables investors, manufacturers, and borrowers to operate financial products remotely, which greatly impacts financial performance, hence providing greater chances for steady growth.

\section{Conclusions}

This study focused on analyzing sharia-based corporate financing in two countries with the world's largest Muslim populations. To investigate a robust comparison of Islamic financing, two primary sources of finance were identified through the literature and evaluated to examine the impact in the short and long term on economic growth in Indonesia and Pakistan.

The findings of this study indicate that financing from debt has more impact on economic growth than issuing shares. From the perspective of a long-term relationship, for the country with the largest Muslim population globally, Islamic equity financing has a negative and insignificant impact on economic growth in Indonesia but has a positive and significant impact on Pakistan. The reduction in the volume of Islamic market capitalization in Indonesia advocates a negative relationship. However, the results have implications on stock-market regulators and investors to encourage investment in Islamic stocks to have a defining role in achieving sustainable economic growth. Meanwhile, bank-based financing has a positive and significant relationship to the economic growth of Indonesia and Pakistan. In the short term, financing from the Islamic banking sector boosts economic growth in Indonesia, but different findings are obtained in Pakistan. The relationship of bank-based financing has a negative and significant impact on economic growth, meaning that the higher the debt-based financing is in Pakistan, the lower the economic performance will be.

Although Indonesia and Pakistan are countries with the largest Muslim population globally, they do not guarantee the sustainability of the Islamic financial sector and a positive impact on economic growth. Therefore, government and Islamic finance industry players supporting Islamic financing play an essential role in encouraging corporate financing from Islamic banks and equity. The efficiency of the financial system can continue to be developed and promote short-and long-term economic growth in Indonesia and Pakistan. Furthermore, the research may further be refined by considering the major markets of Islamic finance.

\section{Limitation and Future Directions}

Our paper has some limitations in terms of the availability of data. For instance, data for the market capitalization of Islamic stock markets were not readily available. Further, in the majority of countries, Islamic banking gained popularity after the US credit crunch. However, if data could be arranged for market capitalization and Islamic banking development for a longer period, the research can provide considerably generalized results. Furthermore, future research can be extended geographically by considering those countries or regions with functional Islamic banking and Islamic stock markets. Nevertheless, considering the core markets of global Islamic finance would provide robust and 
generalized results. Importantly, we ignored the Islamic bond (sukuk) markets due to the limitation of resources. The contribution of Islamic bonds and the interactive role of Islamic banking and the capital market would also provide valuable contributions in the future.

Author Contributions: A.S., B.S., and J.S. worked on the conceptualization and research design, investigation, data analysis, software, and methodology. J.S. contributed to the review, supervision, methodology, software, and discussion part. J.B. contributed to the review, supervision, and editing of the paper. All authors have read and agreed to the published version of the manuscript.

Funding: This research received no external funding.

Institutional Review Board Statement: Not applicable.

Informed Consent Statement: Not applicable.

Data Availability Statement: Data are sourced from the World Development Indicator (WDI), the Pakistan Stock Exchange (PSX), Statistics Indonesia (BPS), and State bank of Pakistan (SBP), which are available on demand.

Acknowledgments: The authors would like to thank the Hungarian University of Agriculture and Life Sciences, Hungary, Budapest Business School, and Tempus Public Foundation for their support. Moreover, the authors would like to appreciate the efforts of the editor and reviewers who provided valuable comments and helped improve the quality of this research.

Conflicts of Interest: The authors declare no conflict of interest.

\section{References}

1. Livoreka, B.; Hetemi, A.; Shala, A.; Hoti, A.; Asllanaj, R. Theories on Dividend Policy Empirical Research in Joint Stock Companies in Kosovo. Procedia Econ. Financ. 2014, 14, 387-396. [CrossRef]

2. Drake, P.P.; Fabozzi, F.J. The Basics of Finance: An Introduction to Financial Markets, Business Finance, and Portfolio Management; John Wiley \& Sons: Hoboken, NJ, USA, 2010; Volume 192.

3. Yıldırım, D.; Çelik, A.K. Testing the pecking order theory of capital structure: Evidence from Turkey using panel quantile regression approach. Borsa Istanb. Rev. 2020. [CrossRef]

4. Banerjee, R.; Illes, A.; Kharroubi, E.; Garralda, J.M.S. Covid-19 and Corporate Sector Liquidity; Bank for International Settlements: Basel, Switzerland, 2020.

5. Zhang, D.; Cai, J.; Dickinson, D.G.; Kutan, A.M. Non-performing loans, moral hazard and regulation of the Chinese commercial banking system. J. Bank. Financ. 2016, 63, 48-60. [CrossRef]

6. Levine, R.; Zervos, S. Stock markets, banks, and economic growth. Am. Econ. Rev. 1998, 88, 537-558.

7. Gambacorta, L.; Tsatsaronis, K.; Yang, J. International banking and financial market developments. BIS Q. Rev. 2014, 3, 1-45.

8. Chakraborty, S.; Ray, T. Bank-based versus market-based financial systems: A growth-theoretic analysis. J. Monet. Econ. 2006, 53, 329-350. [CrossRef]

9. Demirgüç-Kunt, A.; Feyen, E.; Levine, R. The Evolving Importance of Banks and Securities Markets. World Bank Econ. Rev. 2012, 27, 476-490. [CrossRef]

10. Arize, A.; Kalu, E.U.; Nkwor, N.N. Banks versus markets: Do they compete, complement or Co-evolve in the Nigerian financial system? An ARDL approach. Res. Int. Bus. Financ. 2018, 45, 427-434. [CrossRef]

11. Meslier, C.; Risfandy, T.; Tarazi, A. Islamic banks' equity financing, Shariah supervisory board, and banking environments. Pac.-Basin Financ. J. 2020, 62, 101354. [CrossRef]

12. Osoro, J.; Osano, E. Bank-based Versus Market-based Financial System: Does Evidence Justify the Dichotomy in the Context of Kenya. In Kenya Bankers Association Centre for Research on Financial Markets and Policy Working Paper; Kenya Bankers Association: Nairobi, Kenya, 2014; Volume 10.

13. Zhang, L.; Zhang, S.; Guo, Y. The effects of equity financing and debt financing on technological innovation: Evidence from developed countries. Balt. J. Manag. 2019, 14, 698-715. [CrossRef]

14. Saleem, A.; Sági, J.; Setiawan, B. Islamic Financial Depth, Financial Intermediation, and Sustainable Economic Growth: ARDL Approach. Economies 2021, 9, 49. [CrossRef]

15. Setiawan, B.; Saleem, A.; Nathan, R.J.; Zeman, Z.; Magda, R.; Barczi, J. Financial market development and economic growth: Evidence from asean and cee region. Pol. J. Manag. Stud. 2021, 23, 481-494. [CrossRef]

16. Klapper, L.; El-Zoghbi, M.; Hess, J. Achieving the sustainable development goals. J. Int. Bus. Ethics 2016, 8, 53-62.

17. Levine, R. Bank-Based or Market-Based Financial Systems: Which Is Better? J. Financ. Intermediation 2002, 11, 398-428. [CrossRef]

18. Bats, J.V.; Houben, A.C. Bank-based versus market-based financing: Implications for systemic risk. J. Bank. Financ. 2020, 114, 105776. [CrossRef]

19. Song, F.; Thakor, A.V. Financial System Architecture and the Co-evolution of Banks and Capital Markets. Econ. J. 2010, 120, 1021-1055. [CrossRef] 
20. Song, F.; Thakor, A. Banks and capital markets as a coevolving financial system. VoxEU. org 2010, 1, 25.

21. Kammer, M.A.; Norat, M.M.; Pinon, M.M.; Prasad, A.; Towe, M.C.M.; Zeidane, M.Z. Islamic Finance: Opportunities, Challenges, and Policy Options; International Monetary Fund: Washington, DC, USA, 2015.

22. Abraham, F.; Cortina, J.J.; Schmukler, S.L. The rise of domestic capital markets for corporate financing: Lessons from East Asia. J. Bank. Financ. 2021, 122, 105987. [CrossRef]

23. Ongena, S.; Pinoli, S.; Rossi, P.; Scopelliti, A. Bank credit and market-based finance for corporations: The effects of minibond issuances. SSRN Electron. J. 2021, 1315. [CrossRef]

24. Ahmed, A.; Wahid, A.N. Financial structure and economic growth link in African countries: A panel cointegration analysis. J. Econ. Stud. 2011, 38, 331-357. [CrossRef]

25. Hoshi, T.; Kashyap, A.; Scharfstein, D. The role of banks in reducing the costs of financial distress in Japan. J. Financ. Econ. 1990, 27, 67-88. [CrossRef]

26. Nyasha, S.; Odhiambo, N.M. Do banks and stock markets spur economic growth? Kenya's experience. Int. J. Sustain. Econ. 2015, 7, 54. [CrossRef]

27. Rioja, F.; Valev, N. Stock markets, banks and the sources of economic growth in low and high income countries. J. Econ. Finance 2011, 38, 302-320. [CrossRef]

28. Ugolini, S. The coevolution of banks and corporate securities markets: The financing of Belgium's industrial take-off in the 1830s. Bus. Hist. 2019, 1-22. [CrossRef]

29. Asteriou, D.; Spanos, K. The relationship between financial development and economic growth during the recent crisis: Evidence from the EU. Financ. Res. Lett. 2019, 28, 238-245. [CrossRef]

30. Durusu-Ciftci, D.; Ispir, M.S.; Yetkiner, H. Financial development and economic growth: Some theory and more evidence. J. Policy Model. 2017, 39, 290-306. [CrossRef]

31. Fianto, B.A.; Gan, C.; Hu, B.; Roudaki, J. Equity financing and debt-based financing: Evidence from Islamic microfinance institutions in Indonesia. Pac.-Basin Financ. J. 2018, 52, 163-172. [CrossRef]

32. Zarrouk, H.; El Ghak, T.; Abu Al Haija, E. Financial development, Islamic finance and economic growth: Evidence of the UAE. J. Islam. Account. Bus. Res. 2017, 8, 2-22. [CrossRef]

33. Wahyudi, R.; Mujibatun, S.; Riduwan, R. Debt and Equity-Based Financing, Size And Islamic Banks Profitability: Empirical Evidence From Indonesia. Iqtishadia 2019, 12, 227-239. [CrossRef]

34. Khan, M.A.; Hussin, N. Islamic Banking in India: Developments, Prospects and Challenges. Int. J. Res. Commer. Manag. 2013, 4, 25.

35. Pesaran, M.H.; Shin, Y.; Smithc, R.J. Bounds testing approaches to the analysis of level relationships. J. Appl. Econ. 2001, 16, 289-326. [CrossRef]

36. Johansen, S.; Juselius, K. Maximum likelihood estimation and inference on cointegration-With appucations to the demand for money. Oxf. Bull. Econ. Stat. 1990, 52, 169-210. [CrossRef]

37. Narayan, P.K. The saving and investment nexus for China: Evidence from cointegration tests. Appl. Econ. 2005, 37, 1979-1990. [CrossRef]

38. Menegaki, A.N. The ARDL Method in the Energy-Growth Nexus Field; Best Implementation Strategies. Economies 2019, 7, 105. [CrossRef]

39. Kassim, S. Islamic finance and economic growth: The Malaysian experience. Glob. Financ. J. 2016, 30, 66-76. [CrossRef]

40. Conboy, K.; Mikalef, P.; Dennehy, D.; Krogstie, J. Using business analytics to enhance dynamic capabilities in operations research: A case analysis and research agenda. Eur. J. Oper. Res. 2020, 281, 656-672. [CrossRef]

41. van de Wetering, R.; Mikalef, P.; Helms, R. Driving organizational sustainability-oriented innovation capabilities: A complex adaptive systems perspective. Curr. Opin. Environ. Sustain. 2017, 28, 71-79. [CrossRef] 